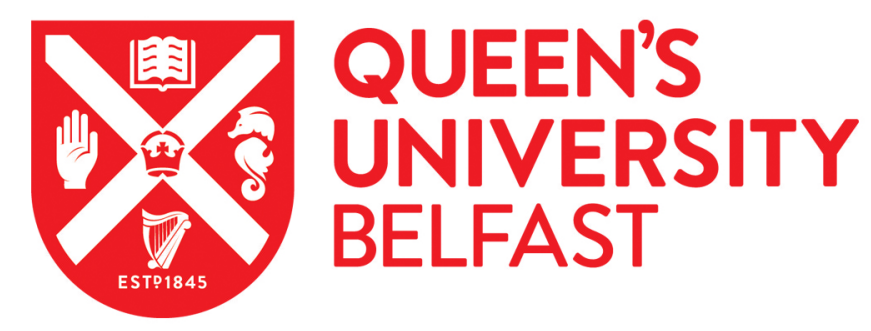

\title{
Cause Lawyers, Political Violence and Professionalism in Conflict
}

McEvoy, K. (2019). Cause Lawyers, Political Violence and Professionalism in Conflict. Journal of Law and Society, 46(4), 529-558. https://doi.org/10.1111/jols.12188

Published in:

Journal of Law and Society

Document Version:

Peer reviewed version

Queen's University Belfast - Research Portal:

Link to publication record in Queen's University Belfast Research Portal

Publisher rights

copyright 2019 Wiley. This work is made available online in accordance with the publisher's policies. Please refer to any applicable terms of use of the publisher.

\section{General rights}

Copyright for the publications made accessible via the Queen's University Belfast Research Portal is retained by the author(s) and / or other copyright owners and it is a condition of accessing these publications that users recognise and abide by the legal requirements associated with these rights.

Take down policy

The Research Portal is Queen's institutional repository that provides access to Queen's research output. Every effort has been made to ensure that content in the Research Portal does not infringe any person's rights, or applicable UK laws. If you discover content in the Research Portal that you believe breaches copyright or violates any law, please contact openaccess@qub.ac.uk. 
Accepted for Publication, Journal of Law and Society 2019, 46, 4 Winter issue. (pre-publication unproofed version)

\title{
Cause-Lawyers, Political Violence and Professionalism in Conflict ${ }^{1}$
}

\author{
Kieran McEvoy ${ }^{2}$
}

\begin{abstract}
This article examines how cause-lawyers in conflicted and authoritarian societies balance their professional responsibilities as lawyers with their commitment to a political cause. The paper is drawn from extensive interviews with both lawyers and political activists in a range of societies, in particular South Africa, Israel \Palestine and Chile. Drawing from both the cause-lawyering and professionalism literature, it focuses on the challenges for lawyers in managing relations with violent politically motivated clients and their movements. Using the notion of 'legitimation work', the paper seeks to examine the complex, fluid and contingent understandings of legal professionalism that is developed in such contexts. The paper offers three overlapping 'ideal types' of cause-lawyers in order to better understand the meaning of legal professionalism in such sites: (a) struggle lawyers (b) human rights activists and (c) a 'pragmatic moral community'. It concludes by re-examining the different ways in which law is imagined in the legitimation work of cause-lawyers in such settings and how that work is remembered in the transition from violence.
\end{abstract}

\section{INTRODUCTION}

The fact is that for much of my life I have lived simultaneously as lawyer and as outlaw. Anyone who has been in clandestinity will know how split the psyche becomes when you work through the law in the public sphere, and against the law in the under-ground. ${ }^{3}$

This article has its origins in a longstanding interest in the dialectic relationship between lawyers and clients engaged in politically motivated violence. I have previously conducted research on the role of law and lawyers in the Northern Ireland conflict and transition. ${ }^{4}$ In this article, I will examine the work of cause-lawyers in

\footnotetext{
${ }^{1}$ Previous versions of this paper were presented at various staff seminars and conferences including a JLS symposium in Cardiff in 2016 and as the topic of the Annual Socio-Legal Studies lecture University of Oxford, May 2017. I am grateful for the comments and discussions generated at these events. I am also indebted for comments and suggestions from Ron Dudai Anna Bryson, Gordon Anthony, Christine Bell, Tim Newburn, Shadd Maruna, Aogan Mulcahy, Louise Mallinder, Chris McCrudden, John Morison, Hannah Quirk, Richard Sparks., Justice Kate O'Regan and for excellent research assistance by Kevin Hearty. Finally many thanks to all of those interviewed for their kindness in sharing their stories. Funding was provided by the Economic and Social Research Council (ES/J009849/1). Any remaining errors are my responsibility.

${ }^{2}$ School of Law Queens University of Belfast. BT7 1NN, Northern Ireland. kmcevoy@qub.ac.uk

${ }^{3}$ A. Sachs, The Strange Alchemy of Life and Law (2009), 1.

${ }^{4} \mathrm{~K}$. McEvoy 'Law, Struggle and Political Transformation in Northern Ireland' Journal of Law and Society (2000) 27.4 542; K. McEvoy 'What Did the Lawyers Do During the "War"? Neutrality, Conflict and the Culture of Quietism' Modern Law Review (2011) 74.3, 350.
} 
Accepted for Publication, Journal of Law and Society 2019, 46, 4 Winter issue. (pre-publication unproofed version)

other conflicted or authoritarian contexts. In particular, through the prism of 'legitimacy work', 5 the article explores how cause-lawyers attempted to balance political commitments with their professional and ethical responsibilities as lawyers in such sites.

Cause-lawyering scholarship has historically focused largely on settled democracies (discussed below). However, there is a nascent literature on cause-lawyers in conflicted, authoritarian and transitional societies. ${ }^{6}$ This scholarship charts legal strategies developed by cause-lawyers, difficult relations with the state (and conventional lawyers) and intimidation and harassment by the state or its proxies.7 The focus of this article is different. Its primary objective is to examine how causelawyers in such contexts deal not with the state, but with politically motivated violent clients and the movements to which they belong.

As is detailed below, some cause-lawyers may have varying degrees of sympathy with the objectives of such individuals and groups. In these contexts, wherein causelawyers may discard the neutral 'hired gun' professional identity, ${ }^{8}$ a key challenge is determining professional and moral guidance regarding relations with such clients and their organisations. Cause-lawyers often have a deep distrust of their own bar associations - thus local bar standards may lack legitimacy or credibility. ${ }^{9}$ They are therefore forced to do their own 'legitimation work' to determine appropriate professional behaviour.

This paper emerges from a larger comparative study of cause-lawyers in six jurisdictions, namely Cambodia, Chile, Israel $\backslash$ Palestine, Tunisia and South Africa. ${ }^{10}$ Given the particular focus in this paper on relations between cause-lawyers and those involved in political violence with whom lawyers had different degrees of sympathy,

\footnotetext{
${ }^{5}$ R. Barker, Legitimating Identities: The Self-Presentations of Rulers and Subjects (2001).

${ }^{6}$ e.g. G. Bisharat, Palestinian Lawyers and Israeli Rule: Law and Disorder in the West Bank (1989); A. Sarat \& Stuart Scheingold, (eds.), Cause Lawyering and the State in a Global Era (2001); L Hajjar, Courting Conflict: The Israeli Court System in The West Bank And Gaza (2005); Halliday, T. et al (eds) (2007) Fighting for Political Freedom (2007); Tam, W. (2013) Legal Mobilization under Authoritarianism: The Case of Post-Colonial Hong Kong; Cheesman, N. Opposing the Rule of Law: How Myanmar's Courts Make Law and Order (2015); Stern, R. 'Activist Lawyers in Post-Tiananmen China.' 42 Law \& Social Inquiry 42, 234.

7 M. Flaherty, 'Human Rights Violation against Defense Lawyers: The Case of Northern Ireland.' (1994) Harv. Hum. Rts. J. 7 87; Human Rights First (2005) Human Rights Defenders and Justice and Accountability in the Americas; Batesmith, A. and Stevens, J. 'In the Absence of the Rule of Law: Everyday Lawyering, Dignity and Resistance in Myanmar's 'Disciplined Democracy' (2018) 28 Social \& Legal Studies, 28, https://doi.org/10.1177/0964663918807739

${ }^{8}$ N. Spaulding 'Reinterpreting Professional Identity.' (2003) U. Colo. L. Rev. 74, 1.

${ }^{9}$ K. McEvoy and R Rebouche 'Mobilising the Professions: Lawyers, Politics and the Collective Legal Conscience' in J. Morison, K. McEvoy and G. Anthony (eds) Judges, Transition and Human Rights (2007) ${ }^{10}$ Other themes examined in the study have included gender and cause-lawyering, cause-lawyering within the state and the cause-lawyering and the boycott of legal proceedings. In this article "Palestine" refers to the West Bank and Gaza Strip which were occupied by Israel in 1967. Some areas of the West Bank are now under partial control of the Palestinian National Authority (PNA), while the Gaza Strip is controlled by Hamas. It was not possible to conduct fieldwork in Gaza for logistical and security reasons. The Palestinian lawyers interviewed practiced law in the Israeli civilian or military courts and/or courts under PNA jurisdiction.
} 
Accepted for Publication, Journal of Law and Society 2019, 46, 4 Winter issue. (pre-publication unproofed version)

the interview data is largely drawn from South Africa, Israel $\backslash$ Palestine and Chile the sites where such dynamics where most pertinent. ${ }^{11}$ The reason for drawing less from the other two sites are as follows. In Cambodia there is no organised armed opposition to the current authoritarian government and none of the lawyers interviewed expressed any sympathy for the previous Khmer Rouge regime. In Tunisia, while some cause-lawyers interviewed had represented alleged Jihadist clients, all those interviewed for this project appeared vehemently opposed to Jihadist violence and the broader Jihadist political project - thus the professional/ethical issues explored herein were less relevant.

I propose three overlapping ideal types of cause-lawyering to serve as heuristic devices to better understand the notion of professionalism with regard to the lawyer client relationship in contexts where lawyers had varying degrees of sympathy for the cause of their client. These ideal types are: cause lawyers as struggle lawyers; cause lawyers as human rights lawyers; and cause lawyers as 'a pragmatic moral community'.

The article seeks to make a number of original contributions to cause-lawyering scholarship. First, while there is a significant literature on the relationship between cause-lawyers and social movements, this paper is the first to offer a comparative exploration of the relationship between cause-lawyering and violent politically motivated movements and individuals. Second, by virtue of its comparative nature, the paper offers an opportunity to both 'make sense of difference' ${ }^{12}$ while offering an opportunity for 'cautious and reflexive' theorising beyond the local experience of the diverse sites. ${ }^{13}$ Third, the realities of lawyering in these extreme circumstances provide a unique opportunity to theorise specifically about lawyers who cross 'the boundaries of the professional project' including becoming involved in 'legally proscribed activities' ${ }^{14}$ Finally, this paper speaks to who and what gets remembered in societies which have experienced violence and authoritarianism - a key transitional justice theme - and cautions against the uncritical valorisation of cause-lawyers.

The article is structured as follows. The paper begins with a necessarily brief overview of the methodology deployed. It then draws out relevant strands from the literature on legitimation work, cause-lawyering, social movements and professionalism in order to inform the subsequent analysis of cause-lawyer/client/movement relationships. Next, I explain the rationale for developing bespoke ideal types of cause-lawyers to examine the intersection between cause-lawyering, professionalism and political violence. The three proposed 'ideal types' of cause lawyers are then

\footnotetext{
${ }^{11}$.For a methodological discussion on strike a balance between 'in case' and 'cross case' study themes in comparative research cases in comparative research see further J. Seawright And J. Gerring, J. (2008) 'Case Selection Techniques in Case Study Research: A Menu of Qualitative and Quantitative Options.' (2008) 61 Political Research Quarterly, 294.

${ }^{12}$ D. Nelken Comparative Criminal Justice: Making Sense of Difference (2010)

${ }^{13}$ R. Cotterell 'Comparative Sociology of Law.' in D Clarke (ed) Comparative Law and Society (2012) p. 60.

${ }^{14}$ S. Sarat and S. Scheingold Cause Lawyering and the State in a Global Era (2001) p. 8
} 
Accepted for Publication, Journal of Law and Society 2019, 46, 4 Winter issue. (pre-publication unproofed version)

explored. The paper concludes by returning to the particular role of law in the legitimacy work of cause-lawyers and how cause-lawyering is remembered in such settings.

\section{METHODOLOGY}

The project from which this paper is drawn involved a comparative study in six jurisdictions. The jurisdictions were chosen to allow 'structured, focused comparisons' between the sites and to facilitate the exploration of a number of theoretical themes. ${ }^{15}$ The rationale for site choice included considerations such as: (a) countries with a history of violence, authoritarianism or which are 'in transition' from such a past; (b) jurisdictions from across the principal 'legal families' (i.e. the Common Law tradition, the Civil Law tradition, Islamic tradition, as well as indigenous Asian and African legal traditions); ${ }^{16}$ (c) jurisdictions with a tradition of cause-lawyering (left or right leaning); and (d) for the 'transitional' sites, jurisdictions with diverse transitional justice mechanisms (e.g. domestic trials, truth commissions, amnesty processes, international justice). Institutional ethical approval was granted before the fieldwork commenced.

The fieldwork was informed by an extensive literature review from a range of disciplines including law, sociology, anthropology, political science and history. Before fieldwork commenced, local researchers were hired to complete a historical report on each site and to attend to in-field logistics. A research instrument (or interview schedule) drawn from the literature was adapted for the particularities of each jurisdiction, albeit with the broader theoretical themes remaining constant across all sites. A total of 131 interviews were carried out across the six sites, with an average of 22 interviews being conducted in each jurisdiction. Eighty of the interviewees were lawyers. A further 10 were with legal academics or judges and 20 were with human rights NGO activists and the rest included politicians, government officials, journalists, civil society actors and a few former political prisoners. Forty of the interviews were with women, and the rest were with men. A purposeful sampling methodology was used to select a diverse range of lawyers based on a range of criteria including professional seniority, experience of conflict or 'struggle' cases and perceived affiliations with diverse political perspectives. These determinations were made with existing networks and contacts and the local researchers. ${ }^{17}$

\footnotetext{
15 A. George 'Case Studies and Theory Development: The Method of Structured, Focused Comparison.' in Alexander L. George: A Pioneer in Political and Social Sciences (2019) pp. 191-214.

${ }^{16}$ G. Patrick, Comparative Legal Families and Comparative Legal Traditions, in M. Reimann and R. Zimmerman (eds) The Oxford Handbook of Comparative Law (2006).

${ }^{17}$ Purposeful or purposive sampling is premised on the assumption that categories of interviewees may have unique, varied or important perspectives on particular themes and therefore ensuring their presence in the sample. For analogous use of similar methodologies with lawyers see e.g. S. O'Donovan-Polten, Constructions of Life Career Success of Eminent Men and Women Lawyers (2001).
} 
Accepted for Publication, Journal of Law and Society 2019, 46, 4 Winter issue. (pre-publication unproofed version)

Almost all interviews were recorded and interviewees specified whether they wished to be named or anonymised. ${ }^{18}$ All interviews were transcribed and the data was thematically coded and analysed using NVivo software, using a fusion of inductive and deductive approaches to coding. ${ }^{19}$ A thematic codebook was developed containing over 30 discrete major codes and over 200 minor codes. Illustrative major codes included the rule of law, legal culture, cause-lawyering, professional neutrality, human rights discourses, strategic litigation and the performance of legality.

Qualitative research, particularly with 'politically conscious actors', ${ }^{20}$ is always vulnerable to the charge that elite level interviewees will speak to a particular political or cultural script. While I make no claims regarding the objective 'truth' of the findings herein, validity checks regarding interviewee data were made before, during and after the fieldwork to verify (as much as possible) the accounts offered.

More broadly, the approach to the fieldwork was to objectively understand the 'subjective meaning' of interviewees' views and actions. This approach reflects what Parker terms (in his analysis of Weber's notion of Verstehen or understanding) 'an attempt to comprehend social action through an empathetic liaison with the actor on the part of the observer. ${ }^{21}$ As Weber himself puts it, 'one need not have been Caesar in order to understand Caesar. ${ }^{22}$ Such an perspective seeks to explore the paths chosen by individual actors and the broader context of those situational choices. We were interested in particular in what Maruna terms the 'self-narratives' of interviewees. ${ }^{23}$ This meant examining how cause-lawyers sense of a professional 'self' was shaped and legitimated by their 'their political beliefs and aspirations', ${ }^{24}$ the structural contexts in which they lived and worked and their relations with others (including clients, political/military movements and of course other lawyers). ${ }^{25}$ As Burger has remarked, for Weber Verstehen is not just a method of investigation at the empirical level, it is also an epistemological requirement for concept formation and explanation. ${ }^{26}$ The ideal types developed below are an effort to do precisely that.

\footnotetext{
${ }^{18}$ Accordingly, some interviewees are named and others are not in this paper.

${ }^{19}$ In broad terms, inductive coding of qualitative data involves a close reading of data to derive concepts, themes or models so that the 'theory emerges from the data'. See J. Corbin and A. Strauss Basics of Qualitative Research $\left(4^{\text {th }}\right.$ ed) (2015) p. 12. A deductive approach explores whether data is consistent with existing theories, assumptions or hypothesis. In practice, most qualitative research involves both. See e.g. J. Fereday and E. Muir-Cochrane. 'Demonstrating Rigor Using Thematic Analysis: A Hybrid Approach of Inductive and Deductive Coding and Theme Development." (2006) International J. of Qualitative Methods 5, 80.

${ }^{20}$ M. Alvesson 'Methodology for Close-Up Studies: Struggling with Closesness and Closure.' (2003) 46 Higher Education, 167.

${ }^{21}$ F. Parkin Max Weber (2002 revised ed) P. 19

${ }^{22}$ M. Weber Economy and Society (1968) p.5.

23 S. Maruna Making Good: How Ex-Convicts Reform and Rebuild Their Lives (2001).

${ }^{24}$ A. Giddens Modernity and Self-Identity: Self and Society in the Late Modern Age (1991).

${ }^{25}$ For an excellent discussion on the interplay between identity, actions, structure and relationships see P Donati Relational Sociology: A New Paradigm for the Social Sciences (2011).

${ }^{26}$ T. Burger Max Weber's Theory of Concept Formation: History, Laws, and Ideal Types (1976) p.10.
} 
Accepted for Publication, Journal of Law and Society 2019, 46, 4 Winter issue. (pre-publication unproofed version)

\section{IDEAL TYPES AND LEGITIMACY WORK AMONGST CAUSE-LAWYERS IN CONFLICTED AND AUTHORITARIAN CONTEXTS}

As noted above, this article offers three 'ideal types' of cause-lawyers in conflict and authoritarian contexts. The development of such typologies or taxonomies has a long history across the social sciences. ${ }^{27}$ Inevitably affected by values and historicallycontingent choices, ${ }^{28}$ ideal types are 'things to think with' or 'ways of seeing', ${ }^{29}$ an 'idealised' version of a particular phenomenon rather than an effort to capture a complete 'reality' ${ }^{30}$ For Weber, ideal types are created by the 'one-sided accentuation' of particular perspectives by synthesising 'diffuse, discrete, more or less present and occasionally absent concrete individual phenomena and then arranging those onesidedly emphasized viewpoints into 'a unified analytical construct' ${ }^{\prime 31}$ Weber viewed ideal types as heuristic instruments to explore the world, ".... neither true nor false, but simply, like any other technical tool, useful or useless". ${ }^{32}$

In the cause-lawyering literature, much of the most influential 'ideal types' scholarship is US based. ${ }^{33}$ For example, Luban has proposed two broad types of cause lawyers - either radical or reformist. ${ }^{34}$ McCann and Silverstein, also based in the US, developed a typology (based on 22 interviews) draw from cause-lawyers in the pay equity and animal rights movements. ${ }^{35}$ They distinguished between 'staff technicians', 'staff activist lawyers', 'hired guns' and 'non-practicing' lawyers. ${ }^{36}$ In a lengthy review article (of Sarat and Scheingold's first two edited collections on the topic-discussed below), Hilbink drew on his doctoral research on US civil rights lawyers to propose three cause-lawyer typologies (proceduralist, elite/vanguard and grassroots), each in turn demarcated by three further distinct sets of characteristics (views of the legal system, views of cause, views of lawyer and client). ${ }^{37}$ Drawing on this US research, Liu and Halliday have developed five ideal types of criminal lawyers - each

\footnotetext{
${ }^{27}$ K. Bailey Typologies and Taxonomies: An Introduction to Classification Techniques (1994).

28 T.Lindbekk "The Weberian Ideal-type: Development and Continuities," (1992) 35 Acta Sociologica, 285.

${ }^{29}$ D. Collier et al 'Putting Typologies to Work: Concept Formation, Measurement and Analytical Rigor," (2012) 65 Political Research Quarterly 217, p. 222.

${ }^{30}$ M. Weber 'Objectivity" in Social Science and Social Policy,' in E. Shils and A Henry The Methodology Of The Social Sciences. (original 1904, trans.1949) p.90.

${ }^{31}$ M. Weber quoted in L Coser, Masters of Sociological Thought: Ideas in Historical and Social Context (1977) (2dn ed) p. 223

32 J. Freund The Sociology Of Max Weber (1968) p. 68.

33 For an exception, see S. Boukalas 'Politics as Legal Action/Lawyers As Political Actors: Towards A Reconceptualisation Of Cause Lawyering. ' (2013) 22 Social \& Legal Studies 395.

${ }^{34}$ D. Luban 'The Moral Complexity of Cause Lawyers Within the State.' (2012) Fordham L. Rev., 81, 705.

${ }^{35}$ M. McCann and H. Silverstein. 'Rethinking Law's Allurements: A Relational Analysis of Social Movement Lawyers in the United States in A. Sarat and S. Scheingold (eds) Cause lawyering: Political Commitments and Professional Responsibilities (1998) 261.

36 ibid p.279.

${ }^{37}$ T. Hibink 'You Know the Type: Categories of Cause Lawyers, (2004) 29 Law \& Social Inquiry 657.
} 
Accepted for Publication, Journal of Law and Society 2019, 46, 4 Winter issue. (pre-publication unproofed version)

distinguished by the extent to which they were politically embedded (or not) and politically liberal (or not). ${ }^{38}$

While I initially considered attempting to organise this project data into variants of these and other ideal types, I ultimately opted to develop my own i.e. cause lawyers as (a) struggle lawyers (b) human rights activists and (c) 'a pragmatic moral community'. The logic of developing such categories was as follows.

First, in line with Weber's emphasis on the usefulness of ideal types, I found that trying to map the experiences of the cause-lawyers we interviewed onto models developed elsewhere was unwieldy and unilluminating. While the simplicity of Luban's typologies are appealing, they refer to cause-lawyers who work within state structures - which is not the focus of this article. Hilbink's distinctions between cause-lawyer typologies did not really resonate in the contexts studied - most would probably have been grouped into only one category (grassroots lawyers) where law and politics are 'melded' and where lawyers 'work closely with and in solidarity with social movements'. ${ }^{39}$ McCann and Silverstein's work was based (with the exception of the 'hired guns') largely on lawyers who were actually embedded within the various activist organisational structures - which was not the case with most of our interviewees. Liu and Halliday's work was focused on criminal lawyers in general rather than cause-lawyers and Boukalas' six ideal types (based on reviews of the literature) were just too complex for analytical clarity.

Second, while there is a tendency in the field of transitional justice to over-state the 'exceptional' nature of the field of study, ${ }^{40}$ the sites in which this fieldwork were conducted were extremely challenging for cause-lawyers. These lawyers operated in contexts of extensive state and (in all but Cambodia) non-state violence. In addition, some of the lawyers interviewed were representing clients who were engaged in political violence for a cause for which the lawyers themselves had varying degrees of sympathy.

Third, these ideal types resonated with interviewees. Variants of all three models were referred to by interviewees as they attempted to describe themselves, their colleagues, their work or their understanding of legal professionalism. To reiterate, they are explicitly used heuristically in this paper rather than in an effort to describe the real world. Nonetheless, the fact that versions of these ideal types appeared 'usable' at

\footnotetext{
${ }^{38}$ Liu, S. \& T. Halliday 'Political Liberalism and Political Embeddedness: Understanding Politics in the Work of Chinese Criminal Defense Lawyers, (2011) 54 Law \& Society Review 831, p. 835.

${ }^{39}$ op cit $\mathrm{p} 688$.

${ }^{40}$ E. Posner and Adrian Vermeule (2004) “Transitional Justice as Ordinary Justice," (2004) 117 Harvard Law Review 761.
} 
Accepted for Publication, Journal of Law and Society 2019, 46, 4 Winter issue. (pre-publication unproofed version)

some level for cause lawyers themselves trying to make sense of the 'reality of life' was reassuring that they had some analytical utility. ${ }^{41}$

Fourth, part of the rationale for the development of these ideal types was that they should help illuminate how lawyers constructed their professional and moral framework in such contexts. As noted above, I have been particularly drawn to Barker's notion of legitimacy work to better understand this process. Barker was in turn influenced by Weber's notion of legitimation as a process or a series of 'observable activities' rather than abstract benchmarks. ${ }^{42}$ Barker's particular focus is on the ways in which those who rule attempt to legitimate their 'identity, status and practices'. He argues that this process of self-legitimation is designed 'to demonstrate, as much to themselves as to others, that they are justified in the pattern of actions that they follow. ${ }^{43}$ Developing the ideal types below helps us see how relations with what Barker termed 'prestigious others' shape the legitimation work of cause-lawyers. He argues that legitimation work and a sense of identity are 'inextricably intermeshed...each is constructed in terms of the other, and each is necessary to make the other comprehensible'. ${ }^{4}$ The prestigious others for the cause lawyers discussed herein include political/armed movements (for struggle lawyers), the international human rights movements (for human rights lawyers) and fellow cause-lawyers (the pragmatic moral community) - all of whom helped shape their responses in determining appropriate courses of action.

I should stress at the outset that each of the ideal types developed here are by definition 'idealised' or exaggerated versions of a particular phenomenon or idea designed to facilitate theoretical discussion of that idea. As such they are constructed in the knowledge that real actors in the 'real world' are affected by multiple variables - which might overlap with features of another ideal type. ${ }^{45}$ Thus, for example, the ideal type of a struggle lawyers would place greatest emphasis on the political struggle as the primary reference point for the management of relations with political motivated clients or their movements. In the real world however, even those who selfidentified as 'struggle lawyers' might well engage with human rights discourses or indeed rely upon a moral community of fellow cause-lawyers.

Before discussing these ideal types of cause-lawyers in more detail, I will now draw out some of the key themes of relevance from the literature concerning cause-lawyers,

\footnotetext{
${ }^{41}$ For a spirited defence of Weberian ideal types as a means of making sense of the reality of life see M. Rosenberg, 'The Conceptual articulation of the reality of life: Max Weber's Theoretical Constitution of Sociological Ideal Types.' (2016) Journal of Classical Sociology, 16, 1, 84.

42 M. Weber Economy and Society (1922) p. 213.

${ }^{43}$ Barker op cit p. 30.

${ }^{44}$ Barker op cit. p. 45-46.

45 J. Lopreato and L. Alston 'Ideal Types and the Idealization Strategy' (1970) 35 American Sociological Review, p. 88
} 
Accepted for Publication, Journal of Law and Society 2019, 46, 4 Winter issue. (pre-publication unproofed version)

their relationship with social movements, the notion of professionalism and how these relate to the charged contexts of representing clients involved in political violence.

\section{CAUSE-LAWYERING, SOCIAL MOVEMENTS AND PROFESSIONALISM}

While early work on lawyers and social change can be traced to the early $20^{\text {th }}$ Century, ${ }^{46}$ 'cause-lawyers' has become a particular socio-legal theme since the late 1980s. The prominence of lawyers in the US Civil Rights Movement sparked a particular interest in America, ${ }^{47}$ subsequently extended to the UK, France, India, Thailand, Latin America and elsewhere. ${ }^{48}$ While there are lively definitional debates, cause-lawyering is at its core a form of 'moral activism' which involves '...using legal skills to pursue ends and ideals that transcend client service' ${ }^{49}$ Often juxtaposed to 'conventional lawyering', cause-lawyering 'implies agency and consciousness, political identification, social solidarity and goals' ${ }^{50}$ While it was originally viewed as synonymous with left-leaning or liberal causes, cause-lawyering scholarship in recent years has included a focus on cause-lawyering on issues such as anti-abortion, progun ownership, pro-business and anti-environmental activism, Israeli settlers and cause-lawyering within the state. ${ }^{51}$

As one would expect, there is a significant focus in the literature on the relationship between cause-lawyers and social movements. For example, the classic US expositions by Scheingold on the 'myth of rights' and McCann's 'rights at work' examined the relationship between cause-lawyers and the civil rights and equal pay movements respectively, including critiques of the dangers of an over-reliance on such lawyers. ${ }^{52}$ Subsequently, one of Sarat and Scheingold's collections focuses specifically on 'what cause-lawyers do for and to' social movements including the LGBT community, refugees, as well as anti-abortion and pro-church groups. ${ }^{53}$ However, while the use of

\footnotetext{
${ }^{46}$ E.g. C. Vose Caucasians Only: The Supreme Court, the NAACP and the Restrictive Convenant Cases (1959).

${ }^{47}$ M. McCann, Rights at Work: Pay Equity and the Politics of Legal Mobilization (1994); Sarat and Scheingold (1998) op cit; A Sarat and S. Scheingold (eds) Cause Lawyering and the State in a Global Era (2001); A Sarat and S. Scheingold Something to Believe In: Politics, Professionalism and Cause Lawyering (2004); A Sarat and S. Scheingold (eds) Cause Lawyers and Social Movements (2006); A Sarat and S. Scheingold (eds) The Cultural Lives of Cause Lawyers (2008).

${ }^{48}$ J. Krishnan, 'Lawyering for a Cause and Experiences from Abroad. ' (2006) 94 California. L. Rev. 575 (2006); L. Kawar, 'Legal Mobilization and the Terrain of the State: Creating a Field of Immigrant Rights Lawyering in France and the United States.' (2011) 36 Law \& Soc. Inq. 354 S. Meili, U.K. Refugee Lawyers: Pushing the Boundaries of Domestic Court Acceptance of International Human Rights Law, (2013) 54 B.C.L. Rev. 1123; F. Munger, Thailand's Cause Lawyers and Twenty-First-Century Military Coups: Nation, Identity, and Conflicting Visions of the Rule of Law, (2015) 2 Asian J. of L. \& Soc. 301; R. Perez-Perdomo, 'Lawyers, Rule of Law, and Social Justice: A Latin American Perspective’ (2008) 5 Uni. of St. Thomas L. J. 730 (2008).

${ }^{49}$ Sarat \& Scheingold 2004 op cit, p. 3-4.

${ }^{50}$ L. Hajjar Courting Conflict: The Israeli Court System in the West Bank and Gaza (2005) p. 154.

${ }^{51}$ A. Southworth, Lawyers Of The Right: Professionalizing The Conservative Coalition (2008); C. Bob The Global Right Wing and The Clash Of World Politics (2012); Y Dotan Lawyering for the Rule of Law (2014). R. Dudai, 'Entryism, Mimicry and Victimhood Work: The Adoption of Human Rights Discourse by Right-Wing Groups in Israel' Int. J. of Hum. Rts. (2017) p. 21, 866.

${ }^{52}$ Scheingold, Stuart (2004) The Politics of Rights: Lawyers Public Policy and Political Change. (2 ${ }^{\text {nd }}$ ed); McCann (1994) op cit.

${ }^{53}$ Sarat and Scheingold (2006) op cit.
} 
Accepted for Publication, Journal of Law and Society 2019, 46, 4 Winter issue. (pre-publication unproofed version)

political violence as 'one component of broader repertoires of action' has long been a theme in social movement research, ${ }^{54}$ there is surprisingly little equivalent focus amongst cause-lawyer scholars on lawyers working for violent clients other than those representing alleged violent extremist Islamicist clients in the wake of the $9 / 11 .{ }^{55}$

As is examined further below, a central concern for cause-lawyers who decide to 'take sides' is how such engagement squares with the idea of legal professionalism. The sociology of the professions has stimulated sophisticated scholarship on the diverse meanings attached to professionalism. ${ }^{56}$ For this article, I have drawn in particular on the value systems that are inculcated and practices that are normalised under the rubric of professional ethics, the capacity of professionals and professional groupings to effect public change and the ways in which both shape relations between lawyers, their clients and broader social or military movements. ${ }^{57}$

Research on professionalism as a value system explores the ways in which shared education, socialisation, training and peer engagement help shape how individuals 'behave, respond and advise' as well as determine parameters for appropriate professional behaviour. ${ }^{58}$ For some, these professional norms may encourage socially beneficial modes of behaviour beyond the needs of the market or the power of the state bureaucracy. ${ }^{59}$ For others, professionalism is really a self-replicating ideology which justifies market dominance, social and political privilege and the legitimation of the established order. ${ }^{60}$ Indeed Bourdieu has argued that the very concept of a 'profession' is dangerous because it 'neutralises', 'naturalises' and masks the 'space of competition and struggle' that lies behind the term. ${ }^{61}$ From such a vantage point, professionalism is a set of useful discourses (in Foucauldian terms) designed to 'govern at a distance' - regulating professionals themselves while also encouraging the co-option of expertise to rationalise state authority. ${ }^{62}$

\footnotetext{
${ }^{54}$ L Bosi, \& S Malthaner, Political Violence, in D. Della Porta and M Diani (eds) The Oxford Handbook Of Social Movements 439, p. 441. See also D. Della Porta, Social Movements, Political Violence and The State (1995); C. Tilly, The Politics of Collective Violence (2003).

55 E.g. M. Denbeaux \& J. Hafetz (eds) The Guantanamo Lawyers (2009); D. Prabhat, Unleashing the Force of Law: Legal Mobilisation, National Security, And Basic Freedoms (2016); F Ní Aoláin (2018) 'Lawyers, Military Commissions and the Rule of Law in Democratic States in G. Lennon and C King (eds) Counter-Terrorism, Constitutionalism and Miscarriages of Justice.

56 See e.g. E. Friedson, Professionalism Reborn: Theory Prophecy and Policy (1994): Mike Dent et al (eds), Routledge Companion to Professions and Professionalism (2016).

57 While the legal education received by cause lawyers and their relationship with their regulatory authorities (local bar councils and law societies) were also described by the cause-lawyers interviewed as influential in shaping local legal cultures, neither are the focus of this paper.

58 J. Evetts 'The Sociological Analysis Of Professionalism: Occupational Change In The Professional World' (2003) 18 Int. Soc. 395, p. 401.

59 T. Parsons, The Social System (1951); E Friedson, Professionalism: The Third Logic (2001).

60 T. Johnson, Professions and Power (1972).

${ }^{61}$ See P. Bourdieu \& L. Wacquant, An Invitation To Reflexive Sociology (1992) p. 242-243 (1992). See also W. Schinkel \& M. Noordergraff, Professionalism as Symbolic Capital: Materials For a Bourdieusian Theory of Professionalism, Comp. Soc. (2011) 67.

${ }^{62}$ M. Foucault, The Birth of The Clinic (1973). See also V. Fournier, 'The Appeal To "Professionalism" as a Disciplinary Mechanism' Soc. Rev. (1999) 280.
} 
Accepted for Publication, Journal of Law and Society 2019, 46, 4 Winter issue. (pre-publication unproofed version)

Within the sociology of the legal profession, professionalism has long been 'taken seriously'. ${ }^{63}$ There is extensive scholarship on 'value system' and 'professional ethics', the relationship between legal professionalism and social or political change and localised discourses on professionalism in diverse locations and settings. There is also a rich literature on lawyer-client relationships, including (most relevant for current purposes) what lawyers should or should not do to defend the interests of a client. ${ }^{64}$ For some, the lawyer's role is to be the 'friend' to the client, ${ }^{65}$ prioritising his/her interests over all others. For others, the lawyer is an 'amoral' actor once the attorneyclient relationship is triggered, so long as what the lawyer does is lawful.' ${ }^{66}$ For the relatively few scholars who discuss the ethics of cause-lawyers, the focus is often on the tensions between the needs of the individual client versus the broader social or political 'cause' ${ }^{67}$ However, for both cause-lawyers and their conventional colleagues, 'fidelity to the law' is largely a given. ${ }^{68}$ Of course such fidelity is easier when lawyers are not working in legal systems where, despite occasional victories, law is inevitably an instrument of repression and state violence. Some cause-lawyers we interviewed broke the criminal law and their professional codes of conduct. However, as is detailed below, few appeared to completely abandon their commitment to some version of the rule of law. ${ }^{69}$

Informed by these understandings of lawyer-social movement relations, professionalism, and lawyer-client relationships, I offer below three overlapping ideal types of how cause-lawyers managed relations with their politically motivated clients and the movements to which they belong in conflicted and authoritarian societies.

\section{CAUSE LAWYERS AS STRUGGLE LAWYERS}

As a struggle lawyer, the government was the enemy. And my objective was to play a role as a lawyer to achieve the objective of the struggle but applying the tools of advocacy and legal activism..$^{70}$

\footnotetext{
63 See Richard Abel, Taking Professionalism Seriously, Annual Survey of American. Law (1989) 41.

${ }^{64}$ G. Hanlon, Lawyers, The State and The Market: Professionalism Revisited (1998); D. Rhode (ed.), Ethics In Practice: Lawyers' Roles, Responsibilities And Regulations (2000); R. Abel, English Lawyers: Between Market and State (2003); D Luban (1988) op cit; W. Wendel, Lawyers and Fidelity to Law (2010); Y. Dezalay \& B. Garth (eds), Lawyers and The Rule Of Law In An Era Of Globalization (2011); A. Francis, At the Edge of Law: Emergent and Divergent Models of Legal Professionalism (2016).

${ }^{65}$ C. Fried, The Lawyer as Friend: The Moral Foundations of Lawyer Client Relation, (1976) Yale L. J. 1059.

66 S. Pepper, 'The Lawyer's Amoral Ethical Role: A Defense, A Problem, And Some Possibilities' (1986) 11 Law \& Social Inquiry 613; Richard Wassertrom, Lawyers as Professionals: Some Moral Issues, 5 Hum. Rts. 1 (1975). As is discussed further below, some authors have suggested a greater space for moral reasoning in defining the limits of lawyer-client relations - e.g. Luban 1988 op cit, and D. Luban, Lawyers and Human Dignity (2007).

${ }^{67}$ e.g. M. Etienne, 'The Ethics of Cause Lawyering: An Empirical Examination of Criminal Defense Lawyers as Cause Lawyers, (2005) 95 Journal of Criminal Law and Criminology, 1195.

${ }^{68}$ W. Wendell, Ethics and Law: An Introduction (2014)

${ }^{69}$ See P. Gowder, The Rule of Law in the Real World (2016) on the contested meaning of the term.

${ }^{70}$ Interview former cause lawyer, South Africa, 15 ${ }^{\text {th }}$ August 2014.
} 
Accepted for Publication, Journal of Law and Society 2019, 46, 4 Winter issue. (pre-publication unproofed version)

Given that so many of the ANC leaders such as Nelson Mandela, Oliver Tambo, Joe Slovo and others were lawyers, it is little wonder that the term 'struggle lawyer' has become synonymous with the South African anti-Apartheid movement. ${ }^{71}$ However, the term had also had resonance in Chile, Israel and Palestine. Of course, the role of lawyers as part of revolutionary struggles predates much of the cause-lawyering literature by some distance. Lawyers feature prominently in the American and French Revolutions and the Irish independence struggle..$^{72}$ In Russia, Lenin (himself a lawyer), was famously wary of 'the dirty tricks of these intellectualist scum [lawyers]' possibly blunting the ardour of the communist revolution'. ${ }^{73}$ In the 1960s, self-proclaimed radical lawyers debated endlessly on the appropriate role for lawyers in promoting 'revolutionary programs' in the struggle against capitalism. ${ }^{74}$

For lawyers who have a direct affiliation with political or military struggle, there is obviously a wide spectrum of styles of engagement. While intimidation by the police or military was common across the sites, none of the cause-lawyers we interviewed suggested they had been coerced or threatened by their own clients or affiliated organisations. ${ }^{75}$ Similarly, no cause-lawyer claimed that they were simply acting 'under orders' having 'signed up to the struggle'. Instead, many saw themselves as committed to the political struggle, self-consciously 'choosing sides' in Scheingold's terms. ${ }^{76}$ As one veteran Marxist lawyer told us concerning his activities in Pinochet era Chile.

We were part of the struggle against the dictatorship. As for the accusation that we are not impartial or not neutral vis a vis politics, my answer is 'yeah duh'...The Executive Secretary of CODEPU was assassinated as were others. I mean attempting to be neutral, it's just not possible...It's not a matter of left or right, it is not even an ethical issue. ${ }^{77}$

Most interviewees were more forthcoming about the ethical challenges involved for struggle lawyers. One South African interviewee discussed what he termed 'struggle ethics' - a process whereby struggle lawyers had to weigh up their own legal and ethical codes alongside the needs of the broader anti-Apartheid struggle. ${ }^{78}$ This interviewee discussed a willingness to countenance illegal activities but weighing

\footnotetext{
${ }^{71}$ R Abel Politics By Other Means (1994)

${ }^{72}$ D. Bell Lawyers and Citizens (1994); H. Lambeth 'The Lawyers Who Signed the Declaration of Independence, (1976) 62 American Bar Association Journal 869; H. Laird Subversive Law in Ireland 1879-1920 (2005).

${ }^{73}$ V. Lenin, Lenin, Collected Works (1962 republished), p. 66.

${ }^{74}$ R. Wassertrom 'Lawyers and Revolution,' (1968) 30 University of Pittsburgh Law Review, 125.

${ }^{75}$ See further Lawyers Without Borders (2013) From Legal Warfare to Peace without Justice (2013) on attacks and intimidation against lawyers.

${ }^{76}$ S. Scheingold The Struggle to Politicise Legal Practice: A Case Study of Left Activists Lawyering in Seattle.' In A. Sarat and S. Scheingold (1988) at p. 18

${ }^{77}$ Interview 30th April 2014. CODEPU was a left-wing lawyers group established explicitly to defend those accused of armed resistance to the Pinochet regime. See further C Collins Lawyers and Transition in Chile (2015).

${ }^{78}$ Interview former cause lawyer now a Minister, $14^{\text {th }}$ August 2014. See e.g. A. Du Toit and N. Mangani (1990)

Political Violence and the Struggle (1990).
} 
Accepted for Publication, Journal of Law and Society 2019, 46, 4 Winter issue. (pre-publication unproofed version)

these up against the consequences (of the action and of getting caught) and the utility of such actions to the broader struggle on a case by case basis. Amongst the biggest ethical challenges identified by struggle lawyers included the interaction with the revolutionary movements to which they were/are affiliated; managing relations with individual clients; and balancing how both sets of relations affected the conduct of politically sensitive trials.

With regard to relations between struggle lawyers and broader revolutionary 'movements', the conflicted or authoritarian contexts provided interesting divergences from the broader cause-lawyering social movement literature. ${ }^{79}$ In particular, as I have discussed elsewhere, many struggle lawyers discussed how the much discussed impulse towards legal dominance was muted by being part of the broader movement. ${ }^{80}$ In large part, this was a recognition of the power of the broader social and political movement. As one Palestinian lawyer put it directly, 'Lawyers are simply a tool... I am not a decision maker. I am simply a tool' ${ }^{81}$ Another interviewee told us:

it certainly wasn't a case of $X$ or $Y$ struggle lawyer saying to Jay Naidoo or to Cyril Ramaphosa do this do that...these are very strong, highly intelligent, very committed people who'd been to jail. They're not going to sort of sit back and listen to a lawyer wax lyrical. I think they would take advice, you'd discuss it, but it wasn't a question of struggle lawyers giving advice in a sort of hierarchical or autocratic manner. They would have told us to piss off, you know. ${ }^{82}$

We were particularly interested to explore what cause-lawyers would or would not do at the nexus between individual clients and the movement. As is discussed elsewhere, communication between politically motivated prisoners and the movement on the outside is crucial to political and military strategy, sustaining morale and human relations and internal security. ${ }^{83}$ Given that such prisoners are usually held in maximum security prisons, professional visits from lawyers become a key link to life beyond the prison. We therefore asked lawyers who represented such clients whether they would pass information between prisoners and the movement on the outside. For some self-described struggle lawyers, this role appeared relatively unproblematic.

\footnotetext{
79 McCann (1994) op cit; S. Barclay et al 'Two Spinning Wheels: Studying Law and Social Movements.' In Austin Sarat (ed) Studies in Law, Politics and Society: Special Issue Social Movements/Legal Possibilities (2011). 80 Bryson, A. and K. McEvoy. Women Lawyers and the Struggle for Change in Conflict and Transition. (2016) Australian Feminist Law Journal, 42(1), 51.

${ }^{81}$ Interview Palestinian cause lawyer, 19th May 2014.

${ }^{82}$ Interview, South African cause lawyer, $14^{\text {th }}$ August 2014. Naidoo was founding General Secretary of the Congress of South African Trade Unions (COSATU). Ramaphosa was former leader of National Union of Mineworkers, chief ANC negotiator and is now the State President of South Africa. Both were former clients of this interviewee.

${ }^{83}$ F. Buntman Robben Island and Prisoner Resistance to Apartheid (2003); E. Nashif, Palestinian Political Prisoners: Identity and Community (2008).
} 
Accepted for Publication, Journal of Law and Society 2019, 46, 4 Winter issue. (pre-publication unproofed version)

I did a lot of couriering. I was the main courier at one point between Robben Island, Lusaka and the leadership in the country, because I knew that I'm not going to restrict my matters to legal duties. I smuggled documents out from prison...I believe that in any conflict situation it is very difficult for a lawyer to be strictly a lawyer. ${ }^{84}$

For others however, while acknowledging a degree of unease, such communication was justified both politically and legalistically. One interviewee rationalised such communication as part of the broader process of 'taking instructions' from one's client. ${ }^{85}$ Another struggle lawyer suggested that he would sometimes refuse to carry such information, but in part because of the risk that one's client could have been 'turned' by the authorities in an effort to entrap struggle lawyers. ${ }^{86}$ Others took the view that risks for such lawyers was too great and simply refused to do it - working on the assumption that the movement would see 'the big picture' regarding such a stance. ${ }^{87}$

The capacity of political/military movements to do precisely that vis a vis relations with cause-lawyers was also evident in the research. For example, one former political prisoner from the Palestinian Fatah faction told us that he would never ask a lawyer to compromise him or herself in such a fashion,'[o]ur organisation know that the lawyer is a lawyer, not to ask him to do more than he can'. ${ }^{88}$ Another distinguished former struggle lawyer recounted an incident as part of a broader self-deprecating account of his own 'military ineptitude'.

I once said to Joe Slovo [MK leader], if you looked over Cape Town from my office, over the public gardens, you could see the roof of Parliament. And I told him that if somebody used our building they could fire mortars onto Parliament. I was a bit disappointed when he turned down the idea, on political grounds that somehow the objective wasn't to kill civilians in Parliament [smiles ruefully]. ${ }^{89}$

From such a perspective, a cold-eyed assessment by violent activists which nudges struggle lawyers away from acts which would compromise them if they got caught (and therefore end their utility to the movement) or indeed curb a lawyer's enthusiasm for half-baked military operations is perfectly rational. That said, the irony of the

\footnotetext{
${ }^{84}$ Interview former South Africa cause lawyer, $12^{\text {th }}$ August 2014. Lusaka (Zambian capital) was the location of the exiled ANC leadership for much of the Apartheid era. Robben Island was the prison which held many of the imprisoned ANC leaders.

${ }^{85}$ Interview former South African cause lawyer, $14^{\text {th }}$ August 2019

${ }^{86}$ Interview former South African cause lawyer, $15^{\text {th }}$ August 2014

${ }^{87}$ Interview Palestine cause lawyer, $19^{\text {th }}$ May 2014.

${ }^{88}$ Interview Palestine, $21^{\text {st }}$ May 2014.

${ }^{89}$ Interview former cause lawyer, political prisoner and judge, South Africa, $12^{\text {th }}$ August 2014. MK, uMkhonto we Sizwe, was the military wing of the African National Congress during the anti-Apartheid struggle.
} 
Accepted for Publication, Journal of Law and Society 2019, 46, 4 Winter issue. (pre-publication unproofed version)

'terrorist' or revolutionary movement keeping struggle lawyers on the 'straight and narrow' is certainly noteworthy.

The final interesting intersection between struggle lawyers, individual clients and the broader political movements is related to high profile political trials. ${ }^{90}$ In the space available, it is not possible to do justice to the nuance and complexity which emerged from the fieldwork across the sites regarding such trials. ${ }^{91}$ For illustrative purposes, I will focus only on South Africa.

Politically motivated defendants have long used their trials both to undermine the legitimacy and rationality of the state and to assert their political agenda. ${ }^{92}$ As Kircheimmer has argued, political trials offer defendants 'one of those rare occasions when the often diffuse conflict between the established authorities and their foes seem to come into sharper focus' ${ }^{93}$ The conduct of defendants at such trials is inevitably shaped by a range of variables including their political and ideological cause, the quality of the state's case, the likelihood of a fair trial, specific defence tactics (e.g. whether the defendants are pleading guilty), whether local legal rules permit the defendant the space to address the court, whether the proceedings are reported by the media and other factors. ${ }^{94}$ Such trials also highlight tensions between the lawyer's tactics and inclinations e.g. deploying legal arguments, language and styles of advocacy designed to persuade a judge - versus the political and ideological urge of activists and their movements to 'make a statement' (sometimes literally). In order for the trial to be transformed into a site of struggle, it requires, at the very least, the acquiescence of the defence lawyers and this is precisely what happened in many prominent political trials. ${ }^{95}$ One South African struggle lawyer summed up the views of many when he said:

\footnotetext{
${ }^{90}$ For current purposes, political trials can be understood broadly as the use of criminal law by the state to prosecute an adversary of the state for politically motivated actions against that state. See O. Kirchheimer Political Justice: The Use of Legal Procedure for Political Ends. (1961).

${ }^{91}$ In very broad terms, in Pinochet's Chile struggle lawyers appeared to largely 'play it straight' at political trials, issued writs of habeus corpus for detained or disappeared activists and generally focused on legal argumentation rather than the political motivation of clients or the context of their offences. In the Israeli military courts, which processes the vast majority of Palestinian politically motivated offences, the conviction rate is $99.7 \%$. Thus in practice much of the work of struggle lawyers is focused on negotiations and plea-bargaining regarding sentence reduction rather than the occupation. See Collins (2015) op cit. and N. Ziv 'Navigating the Judicial Terrain under Israeli Occupation: Palestinian and Israeli Lawyers in the Military Courts' 42 (2018) Fordham ILJ, 729.

${ }^{92}$ I. Balbus, The Dialects of Legal Repression: Black Rebels Before the American Criminal Courts (1977); J. Shklar Legalism: Law Morals and Political Trials (1986); A Allo (ed) The Courtroom as a Space of Resistance; Reflections on the Legacy of the Rivona Trial (2015).

93 Op cit. p. 232.

${ }^{94}$ K. McEvoy (200) op cit.

95 The Rivonia treason trial of Nelson Mandela and his co-accused is a classic example. Mandela used the trial to contest the Apartheid state's right to try him given that he had no democratic voice in the making of such laws. He also outlined the morality of the ANC's sabotage strategy and its alternative vision of a democratic South Africa (see Allo 2015 op cit). Mandela was facilitated in so doing by his lead defence counsel, Bram Fischer. Mr Fischer is a revered struggle lawyer. He was from a privileged Afrikaner legal family, a senior advocate and a leading member of the South African Communist Party. Fischer took state exhibits used during the trial (including detailed maps of possible sabotage targets) and passed them to MK for future armed actions. He was ultimately
} 
Accepted for Publication, Journal of Law and Society 2019, 46, 4 Winter issue. (pre-publication unproofed version)

Political trials had a particular role to play, and as the lawyer you had to facilitate that process. Sometimes all we had to do was to create a platform on which particular highprofile cadres who were coming into the country were given the opportunity of using the trials to further their political positions. ${ }^{96}$

To recapitulate, the struggle lawyer ideal type does not generally translate into an abandonment of all legal and ethical commitment as a lawyer in favour of the needs of the struggle. While some of those interviewed saw the needs of the struggle as paramount in all cases, others appeared to make localised calculations on what they would or would not do, albeit shaped by a calibrated understanding of the needs of that struggle. In other instances, it was the military or political movement itself which provided a check on 'unlawyerly' behaviour. Finally, particularly in South Africa, struggle lawyers also worked closely with their clients (where the latter so desired) to render trials explicit sites of political struggle - decisions which (as in the case of the Rivona trial) sometimes trumped what might have been the legal line of argumentation most likely to succeed. Across these settings, the 'legitimation work' which determined the legal and moral conduct of struggle lawyers was shaped by context specific 'struggle ethics' developed in dialectical interaction with individual clients and their political or military movements. ${ }^{97}$

\section{CAUSE LAWYERS AS HUMAN RIGHTS ACTIVISTS}

I as a human rights lawyer have no position regarding how the Israeli/Palestinian conflict should be resolved - one state, two states - as long as human rights are respected, as long as people are being treated equally. ${ }^{98}$

The second way of seeing the cause-lawyer in such contexts is as a type of human rights activist. Of course, claims-making through human rights discourse has almost become synonymous with legal, political and social struggle. ${ }^{99}$ As one senior former Apartheid era South African state lawyer told us wryly, 'we are all human rights lawyers $n o w^{\prime}{ }^{100}$ Certainly in Northern Ireland lawyers representing politically motivated clients tended to self-identify as 'human rights lawyers' and to stress their professional

convicted of treason, struck off from the bar and sentenced to life imprisonment. He served 15 years before dying of cancer. Fischer later wrote 'When an advocate does what I have done,...it required an act of will to overcome his deeply rooted respect of legality, and he takes the step only when he feels that, whatever the consequences to himself, his political conscience no longer permits him to do otherwise. He does it not because of a desire to be immoral, but to act otherwise would, for him, be immoral' See S. Clingman Bram Fischer: Afrikaner Revolutionary (1998) and S. Ellman 'To Live Outside the Law You Must Be Honest: Bram Fischer and the Meaning of Integrity,' (2000) 6 North Carolina JILCR 767.

${ }^{96}$ Interview former cause lawyer, and judge, South Africa, $11^{\text {th }}$ August 2014.

${ }^{97}$ For a useful discussion on the tensions between professionalism in other occupations and armed struggle see Du Toit \& Mangani (1990) op cit.

${ }^{98}$ Interview Israeli human rights lawyer Michael Sfard, $14^{\text {th }}$ May 2014.

${ }^{99}$ K. Grewal The Socio-Political Practice of Human Rights (2017).

${ }^{100}$ Interview former Apartheid state lawyer, 10 ${ }^{\text {th }}$ August 2014. 
Accepted for Publication, Journal of Law and Society 2019, 46, 4 Winter issue. (pre-publication unproofed version)

neutrality in terms of the broader political conflict. ${ }^{101}$ As noted above, in conflicted or authoritarian societies, a human rights framework can serve as both a shield and a sword for lawyers doing politically sensitive work. As a shield, it grounds their work in the independent legal standards of international human rights and provides a bulwark against the charge that they are terrorist 'fellow travellers'. ${ }^{102}$ It also gives them access to a crucial international human rights network that can provide legitimacy, protection, and international support. ${ }^{103}$ Indeed many of the self-identified human rights lawyers we interviewed had worked with or for local and or international human rights NGOs. As a sword, human rights lawyering also provides a platform for attacking authoritarian governments, critiquing its breaches of binding international treaties or domestic constitutions, and doing so in ways that are more difficult to dismiss than politically motivated opposition.

The 'fit' of human rights activism for cause-lawyers in managing relations with politically motivated clients is also obvious. As noted above, at a practical level, a prime virtue of the 'legalisation of human rights' is precisely its narrow focus on law. ${ }^{104}$ Thus for example, several Israeli interviewees from a Jewish background spoke persuasively about their role as human rights cause lawyers. All were politically opposed to the occupation, but did not necessarily identify fully with their militant Palestinian clients. For example, in defending Hamas activists - while not sharing their political objectives (an Islamic state) or agreeing with their tactics (violence including against Israeli civilians) - the cause of universal human rights (which some of their clients might actually oppose) had obvious appeal. In addition, focusing on law rather than politics may also allow cause-lawyers to build alliances with other less radical lawyers by framing conversations exclusively in legal terms. ${ }^{105}$ More broadly, being seen as a human rights lawyer speaks directly to the professional self-image of cause-lawyers as fighting to achieve a more 'just world'. ${ }^{106}$ However, for other causelawyers, the human rights framework comes at too high a price for at least two reasons.

First, key elements of human rights principles and practices such as universalism and non-discrimination would suggest that cause-lawyers should represent clients from

\footnotetext{
101 K. McEvoy (2011) op cit.

102 The UN Basic Principles on the Role of Lawyers (1990), Principle 18 stipulates 'Lawyers shall not be identified with their clients or their clients' causes as a result of discharging their functions.'

${ }^{103}$ See e.g. the UN Declaration on Human Rights Defenders (2000). For a discussion on the importance of such transnational networks to local human rights activists see e.g. S. Engle Merry, 'Transnational Human rights and Local Activism: Mapping the Middle.' (2006) 108 American Anthropologist, 38. K. Sikkink The Justice Cascade: How Human Rights Prosecutions Are Changing World (2011).

104 J. Donnelly, Jack 'The Virtues of Legalisation,' in S. Meckled García, et al (eds.) The Legalisation of Human Rights (2006) p. 67.

${ }^{105}$ See e.g. A. Sarat 'Recapturing The Spirit of Furman: The American Bar Association and The New Abolitionist Politics, (1998) 61 Law and Contemporary Problems 5. Regarding work of anti-death penalty cause-lawyers with the American Bar Association.

106 G. Frankenberg 'Human Rights and the Belief in a Just World,' (2014) 12 International Journal of Constitutional Law 35.
} 
Accepted for Publication, Journal of Law and Society 2019, 46, 4 Winter issue. (pre-publication unproofed version)

whatever political perspective. For some, that was straightforward. As one of Tunisia's most celebrated human rights lawyers, herself a regular victim of state harassment and abuse, told us; 'I would defend human rights even when the case involves my own enemies. Even if Ben Ali were here now I would defend him'. ${ }^{107}$

For other cause-lawyers however, the human rights obligation to represent individuals from 'the other side' was highly problematic. One former South African cause-lawyer told us he would have 'turfed out' any Apartheid state official who came to his office seeking representation. ${ }^{108}$ A Chilean cause lawyer told us [in response to the question of he would have represented the military or police], '[a]bsolutely not, I represent victims not perpetrators' ${ }^{\prime}{ }^{109}$ In a similar vein, veteran Israeli lawyer Lea Tsemel (also interviewed for this research) told a television interviewer that the only Palestinian client I would not represent is a collaborator, someone who collaborates with Israel, someone who sells out his own people'. ${ }^{110}$

The second limitation of the human rights framework for some cause-lawyers was precisely that such discourses lend themselves too readily to ignoring the politics of legal struggle in the context of conflict or authoritarianism. Ignatieff, Kennedy and others have all discussed the 'anti-politics' weakness of some variants of human rights activism which emphasises the universal and legalistic while disavowing the inherently political nature of rights claims and their consequences. ${ }^{111}$ For some cause lawyers the politics of human rights is front and centre. By way of illustration, the widely respected Israeli lawyer Michael Sfard, has argued that 'the most important, the most critical human rights battle of our generation in Israel is the fight against the occupation'.112 Previously he has written of 'the existential dilemma of the human rights lawyer' wondering with regard to the Israeli occupation, '...am I nothing but a collaborator to this huge mechanism, which needs me to occasionally soften the sharp edges of the military domination and hence enable the occupation to operate'. ${ }^{113}$ In discussing the push and pull between the Israeli military and the human rights lawyer, one asking for more power and the other for greater restraint, he suggests that 'both contribute to the workability of the Israeli domination and thus to the durability of the occupation' [author's emphasis]. ${ }^{114}$

\footnotetext{
${ }^{107}$ Interview cause-lawyer, Tunisia, $24^{\text {th }}$ June 2014. Ben Ali was Tunisian President for over 23 years before being forced from office in 2011. His regime was characterised by corruption and human rights abuses. See C Alexander Tunisia: From Stability to Revolution in the Maghreb (2016) (2 $\left.2^{\text {nd }} \mathrm{ed}\right)$.

108 Interview former cause lawyer South Africa, $11^{\text {th }}$ August 2014.

${ }^{109}$ Interview former cause-lawyer, Chile, $29^{\text {th }}$ April 2014.

110 'Israeli Lawyer: Palestinians Have the Right to Fight.' Aljazeera TV 1st August 2015.

${ }^{111}$ See e.g. M Ignatieff, Human Rights as Politics and Ideology (2003) D. Kennedy 'The International Human Rights Movement; Part of the Problem?' (2002) 5 Harvard Human Rights Journal 101.

${ }^{112}$ M. Sfard The Wall and the Gate: Israel, Palestine and the Legal Battle for Human Rights (2018) p.8. Mr Sfard was also interviewed for this project.

${ }^{113}$ M. Sfard 'The Human Rights Lawyer's Existential Dilemma' (2005) 38 Israel Law Review 154, p. 167.

${ }^{114}$ Ibid.
} 
Accepted for Publication, Journal of Law and Society 2019, 46, 4 Winter issue. (pre-publication unproofed version)

Perhaps unsurprisingly, there was more of a tension amongst cause-lawyers who saw themselves as human rights activists (compared to struggle lawyers) regarding the dominance of law and legalism in terms of broader social and political struggle. Some such lawyers were quite honest about their 'urge to litigate' with one self-described Palestinian human rights lawyer likening it to 'the surgeon's desire to cut'. ${ }^{115}$ Certainly amongst NGOs the potential for human rights lawyers to dominate was widely debated in Chile, Tunisia, Israel and Palestine. One former Israeli NGO director told us that she preferred to hire lawyers as needed rather than have an in-house lawyer because human rights lawyers tended to 'narrow the framework of the struggle to what is possible legally' and to 'obstruct my creativity'.116 Another Israeli NGO lawyer and activist described the dynamics thus:

it's a big issue, lawyers becoming alpha activists and sometimes dictating the agenda of the movement...In [NGO name],... when we recruited lawyers, we checked, if this lawyer has an ego, is it small enough to take instructions from a 19 year old girl that knows much more than him because she works in a human rights organisation? ${ }^{117}$

In sum, the human rights lawyer ideal type captures well the work and self-image of many cause-lawyers in conflicted and authoritarian contexts. Notwithstanding the challenges of the human rights framework (including defending the rights of state actors), the gravitational pull of human rights as a sword and shield for cause-lawyers in conflicted or authoritarian contexts is powerful. The familiar risks of legal domination by human rights lawyers is also strong, albeit muted in some contexts by activist NGOs willing to check more hubristic legalistic traits. The 'dilemmas' of representing clients from military or social movements are of course not magically resolved when abstract human rights norms meet the 'messy political, social and personal reality' of such sites but it's a good place to start. ${ }^{118}$ Moreover, when the stakes are high, and the limits of law are obvious, part of the challenge for a causelawyer '... is not to discard rights but to see through or past them'. ${ }^{119}$ Inevitably working through such messiness means seeking advice from fellow cause-lawyers.

\section{CAUSE LAWYERS AS A PRAGMATIC MORAL COMMUNITY}

In this final section I wish to explore the notion of cause-lawyers in conflicted or authoritarian societies as a pragmatic moral community. Of course, those who regard themselves as human rights lawyers or struggle lawyers would share some of the characteristics and forms of action detailed below. The 'causes' pursued with lawyers who fitted with this 'ideal type' - opposition to an authoritarian state or determination

\footnotetext{
115 Interview cause lawyer Israel, $13^{\text {th }}$ May 2014.

${ }^{116}$ Interview $13^{\text {th }}$ May 2014

${ }^{117}$ Interview $11^{\text {th }}$ May 2014.

${ }^{118}$ R. Dudai, 'Rights Choices: Dilemmas of Human Rights Practice,'" (2014) 6 Journal of Human Rights Practice 389 , p.390.

${ }^{119}$ P. Williams, The Alchemy of Race and Rights: Diary of a Law Professor. (1991) p. 164).
} 
Accepted for Publication, Journal of Law and Society 2019, 46, 4 Winter issue. (pre-publication unproofed version)

to uphold international human rights standards - might well resonate. However, our interviews suggested that the ways of navigating complex relations with politically motivated clients and their movements are different for some cause-lawyers. While the 'struggle lawyer' or 'human rights' ideal types of cause-lawyers would of course seek the support of fellow cause-lawyers, they tend to place greatest emphasis on the importance of external reference points ('the struggle' or 'human rights discourses') to determine appropriate courses of action. Those referred to below as belonging to a moral community of cause-lawyers might factor in these or other external reference points but they tended to emphasise pragmatic decision-making based on internal organically constructed values and working practices generated from within communities of cause-lawyers.

The notion of professionals as a moral community is usually traced to Durkheim. Following De Tocqueville, Durkheim viewed professional groupings as a buffer against state tyranny and individual domination. ${ }^{120}$ Within professional groups, he argued, particular professional ethics or morals evolved as 'the product of the professional group', shaped by the particular 'nature' or 'characteristics' of that group'. ${ }^{121}$ Thus lawyers, doctors, accountants or other professionals developed bespoke professional morals according to the nature of their work, their relationship with clients, with civil society and of course with the state. Within certain groupings, as Perry has argued, 'basic moral beliefs are less the property of individuals than of communities'. ${ }^{122}$ For Perry these beliefs about appropriate conduct are part of a continuous 'socially embedded argument' as to how individuals 'should live our public, collective life'. ${ }^{123}$

Given their profession as lawyers, the 'ways of working' developed by moral communities of cause-lawyers were inevitably shaped by their understandings of law, lawyering and legal professionalism. ${ }^{124}$ However, in the pressurised environment of cause-lawyering in these contexts, broader philosophical questions were often supplanted by the need to evolve what Croft has described as 'context-specific codes of conduct.' ${ }^{125}$ As noted above, professional codes of the Bar were often viewed by cause-lawyers as serving the interests of the state. Cause-lawyers were therefore forced to develop, revisit and adapt their own 'codes' in managing relations with politically motivated violent clients. There were myriad 'ways of working' with such clients which emerged as themes from our field-work. Below, I have focused on three

\footnotetext{
${ }^{120}$ A. De Tocqueville Democracy in America (2000); E. Durkheim Professional Ethics and Civil Morals (1950). p.96.

121 Ibid p. 7.

${ }^{122}$ M. Perry (1998) Morality, Politics and Law (1998) p.29.

${ }^{123}$ M. Perry 'The Authority of Text, Tradition and Reason: A Theory of Constitutional Interpretation' (1985) 58 South California Law Review 551, p. 573.

${ }^{124}$ R. Susskind Tomorrows Lawyers: An Introduction to Your Future (2016).

${ }^{125}$ C. Croft 'Reconceptualizing American Legal professionalism: A Proposal for Deliberative Moral Community.' (1992) 67 NYUL Rev., 1256, p. 1325.
} 
Accepted for Publication, Journal of Law and Society 2019, 46, 4 Winter issue. (pre-publication unproofed version)

illustrative examples - an emphasis on the human dignity of clients, the support and guidance of fellow cause-lawyers and a robustness in managing tensions with political or military movements. I will argue that these and related practices informed and were informed by a normative moral framework for ethical behaviour amongst causelawyers.

There is rich literature on the importance of lawyers seeing clients as 'full human beings' to be treated with dignity and respect. ${ }^{126}$ Dignity in this context is more than the formal legal standing of a client as a rights-holder but also, as Waldron has suggested, seeing the client as a 'moral presence' a person with a distinct story to be heard who is to be protected from humiliation. ${ }^{127}$ As Batesmith and Steven (2018) have argued recently with regard to lawyering in Myanmar, these 'softer' elements of the lawyer-client relationship are all the more important in the context of authoritarian or conflicted regimes where the formal guarantees of the rule of law are often hollow promises. ${ }^{128}$ Cause-lawyers we interviewed repeatedly told us of the importance of recognising that their clients had often been tortured, isolated and other-wise illtreated and that the lawyer might be their key 'human face' standing by them 'so they would not feel left alone'129 - treating them as 'a human being with dignity'. ${ }^{130}$ Cause lawyers often passed messages between imprisoned clients and their families concerning very 'personal and emotional topics'. ${ }^{131}$ In Palestine, such empathy is expected and even formalised into an agreement between the lawyers and their clients that '...all the time give some power to the hearts and to the mind of the families and the prisoners' ${ }^{132}$

I would argue that what sets cause-lawyers apart in these contexts, is that such human empathy can morph into something more than professional decency. For some

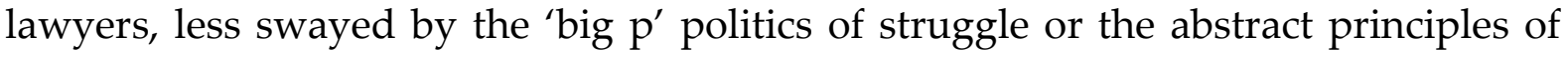
human rights, the plight of individual clients and their families suffering injustice is what nudges them towards self-identifying as a cause-lawyer. As Wilson and Brown have argued, empathy is mobilized more effectively when focused on 'individual suffering' rather than abstract principles or imagined groups. ${ }^{133}$ Certainly we interviewed lawyers across all of the jurisdictions who described precisely such a journey in response to how they became a cause-lawyer. For some, cause-lawyering was an expression of moral empathy and solidarity - a response to an increased

\footnotetext{
126 E. Wald and R. Pearce (2011) "Making Good Lawyers," 9 University of St Thomas Law Journal 403. p. 438. 127 J. Waldron 'How Law Protects Dignity' (2012) 71 Cambridge Law Journal, 200 p. 201; R. Vischer 'How do Lawyers Serve Human Dignity?' (2011) University of St Thomas Law Journal 222.

${ }^{128}$ A Batesmith and J. Stevens 'In the Absence of the Rule of Law: Everyday Lawyering, Dignity and Resistance in Myanmar's 'Disciplined Democracy'. 2018 Social \& Legal Studies

${ }^{129}$ Interview cause-lawyer, Tunisia, $18^{\text {th }}$ June 2014.

${ }^{130}$ Interview former cause-lawyer, South Africa, 14 ${ }^{\text {th }}$ August 2014.

${ }^{131}$ Ibid.

${ }^{132}$ Interview Chair, Palestinian Prisoners Society, $19^{\text {th }}$ May 2014.

${ }^{133}$ R. Wilson and R. Brown 'Introduction' in R. Wilson and R. Brown (eds.) Humanitarianism and Suffering: The Mobilization of Empathy (2008) p. 20.
} 
Accepted for Publication, Journal of Law and Society 2019, 46, 4 Winter issue. (pre-publication unproofed version)

'political moral knowledge' - concerning the injustices suffered by clients, their families and the communities from which they came as well as the context which prompted those clients to become involved in violence in the first place. ${ }^{134}$

Once cause-lawyers begin to see themselves as such, they will inevitably be drawn to seek the advice of practitioners doing similar work, particularly if they are viewed with suspicion by conventional lawyers and the state. ${ }^{135}$ As one Chilean cause lawyer told us, in a context where people were being tortured, murdered and disappeared with apparent impunity, '...the Vicariate was a human space where we all met, where we shared our experiences, and told each other what we were living through'. ${ }^{136}$ Across all of the jurisdictions, cause lawyers continuously told us of the importance of talking to experienced colleagues, 'role models', 'elders' and the like.

That said, as anyone who has worked in the world of cause-lawyering will attest, these are not universally 'easy' or supportive social and political spaces. ${ }^{137}$ There are often fierce contests and rivalries within and between law firms and NGOs on politics, legal strategies and tactics, competition for clients and funding and a range of other factors. Such tensions were manifest in all of the sites reviewed in this study. Nonetheless, for lawyers forced to make tough ethical choices about whether they should or should not break the law or their own professional codes of conduct, such relations were a key resource - a variant of what Bourdieu has termed social capital - '...a durable network of more or less institutionalised relationships'. ${ }^{138}$

A third and related feature of the moral community prism on cause-lawyers is how such lawyers sometimes adopted oppositional positions to the political or military movements to which their clients belonged. The tension between client-focused work and the broader needs of political or social movements is a rich theme in the causelawyering literature. ${ }^{139}$ For struggle lawyers, the normative base for managing such tensions may be the 'big picture' objectives of the struggle trumping unreasonable immediate demands from either client or movement. For human rights activist lawyers, a focus on the individual rights of the client and the broader international human rights framework would be the obvious default source of guidance. However, for cause-lawyers who do not see themselves as either but who are more than just

\footnotetext{
${ }^{134}$ Perry (1985) op cit p. 573.

${ }^{135}$ T. Halliday 'Politics and Civic Professionalism: Legal Elites and Cause Lawyers," (1999) 24 Law \& Social Inquiry, 1013.

${ }^{136}$ Interview former cause-lawyer, Chile, 1st May 2014. The Vicariate of Solidarity, under the rubric of the Catholic Church, became one of the few relatively 'safe spaces' for lawyers to work on human abuses during the dictatorship. See Collins op cit.

${ }^{137}$ In the interests of transparency, the author has been an active member of the principal human rights NGO in Northern Ireland for over twenty-five years.

${ }^{138}$ P. Bourdieu and L. Wacquant An Invitation to Reflexive Sociology (1992) p. 119.

${ }^{139}$ E.g. Sarat and Scheingold 2001 op cit; S. Cummings 'Rethinking the Foundational Critiques of Lawyers in Social Movements.' (2016) 85 Fordham L. Rev. 1987.
} 
Accepted for Publication, Journal of Law and Society 2019, 46, 4 Winter issue. (pre-publication unproofed version)

neutral 'hired guns', what is their framework in deciding which actions will and will not be countenanced?

A key theme which emerged on this point was the importance of pragmatism as well as principle. Many cause-lawyers in settled democracies describe themselves as pragmatic, focused on the symptoms of injustice rather than the required larger political change and well aware of limitations of legal activism. ${ }^{140}$ This self-image as, in effect, principled pragmatists came through strongly in many of our interviews with cause lawyers. Determining appropriate lines to take were viewed by such lawyers as pragmatic problems to be solved, often by taking advice from other similarly minded cause-lawyers. As interviewee told us, '...you ask questions from people with good judgement who you trust, you take their advice and don't do stupid things' ${ }^{141}$ More generally, the confidence for such cause-lawyers to say 'no', to be at odds with the movement, was derived from the knowledge that other respected lawyers took a similar line. Another interviewee illustrated this point well:

There was a protest by a woman's organisation and the police vans pulled up in front. As they [the police] were putting them in the vans, lawyers were present; we took them out of the vans, making a lot of noise about the human rights of these women and so on... One of the comrades who had organised it was screaming 'these damn lawyers', why are they doing that. The point of the protest is for the women to be arrested, you are being a counter-revolutionary. Why are you lawyers undermining our strategy?' I said that our task here was to keep the women out of the cells, your task was to have the women arrested and get into the front page of the Cape Times. ${ }^{142}$

Seeing cause-lawyers as a pragmatic moral community captures the space for fluidity, contest, 'trial and error' problem solving, argument and renegotiation on 'lines to take' in a given context. The work of 'pragmatic actor' sociologists and socio-legal researchers is useful in this regard. Scholars in this area argue that people make moral judgments drawn from the cultural repertoires available to them and then use these standards to draw adaptable but resonant normative boundaries around appropriate behaviour which 'make sense' to those within the group. ${ }^{143}$ Such boundaries should also be capable of being viewed as rational and legitimate (however begrudging) to at least some actors outside the group, including members of a political or military movement, who can at least see the logic of cause-lawyers adopting a stance in opposition to their own. Moral communities of cause-lawyers, working without a clear 'line to take' shaped by the exigencies of struggle or the human rights

\footnotetext{
${ }^{140}$ See e.g. Scheingold and Sarat (2004) op cit p. 111, McCann and Silverstein (op cit 1998) p. 266.

${ }^{141}$ Interview former cause-lawyer, South Africa, 14 ${ }^{\text {th }}$ August 2014

${ }^{142}$ Interview former cause-lawyer, now a judge, South Africa, $11^{\text {th }}$ August 2014.

${ }^{143}$ M. Lamont Money, Morals, and Manners: The Culture of the French and American Upper-Middle Class (1992); L. Boltanski and L. Thévenot 'The Sociology of Critical Capacity,' (2001) 2 European Journal of Social Theory 359; S. Silbey 'The Sociological Citizen: Pragmatic and Relational Regulation in Law and Organizations' (2011) 5 Regulation \& Governance 1.
} 
Accepted for Publication, Journal of Law and Society 2019, 46, 4 Winter issue. (pre-publication unproofed version)

framework, developed their own versions of what Putnam terms a 'social organisation' - one which was shaped by relations of 'trust and norms and networks' - which could in turn facilitate 'coordinated actions' ${ }^{144}$

To recapitulate, cause-lawyers in these contexts developed a series of 'ways of working' which framed the parameters of their relations with politically motivated clients and their movements. These 'ways of working' - informal codes, values or working practices - were shaped and reshaped by continuous deliberations within the moral community. Practical illustrations of such ways of working included an emphasis on the human dignity of their clients, solidarity, support and guidance for other cause-lawyers and the self-assurance to recognise that while clashes with military and political movements will inevitably occur, relations could be maintained.

CONCLUSION: Cause-lawyering, legitimation and struggle remembered

I have argued above that the work of cause-lawyers in these extreme contexts can be better understood through the ideal types of struggle lawyers, human rights lawyers and cause-lawyers as a pragmatic moral community. Drawing from Barker, I have also argued that these overlapping ideal types help illuminate the complex personal and professional legitimation work done by cause-lawyers to rationalise and articulate their professional identity, strategies, relationships and practices. ${ }^{145}$ By viewing causelawyers though a legitimation lens, taking seriously what they say regarding their views and practices, examining their relations with clients and movement and then organising these into ideal types we are better able to see '...the everyday work of constituting coherent worlds' ${ }^{146}$ Given that at some stage many of the cause-lawyers interviewed crossed clear legal and ethical boundaries, their need for self-legitimacy appeared all the more acute. Unsurprisingly, given their profession, attitudes towards law was a key theme in the legitimation work of all the cause-lawyers interviewed.

Again with significant overlap, the three ideal types developed here offer insights into the ways in which law is imagined, realised and discussed amongst cause-lawyers and its role in legitimating ensuing versions of professionalism.

For struggle lawyers, the obvious 'big picture' legitimating framework regarding professional and personal conduct appeared to be the justifiability of the political and/or armed struggle itself. At first blush, the apparent 'justness' of struggles such as that against Apartheid or the Pinochet dictatorship gave struggle lawyers considerable latitude. Some struggle lawyers clearly felt justified in law-breaking

\footnotetext{
${ }^{144}$ R. Putman (1993) Making Democracy Work p. 167.

145 Barker (2001) op cit.

${ }^{146}$ S. Coutin et al 'In the Mirror: The Legitimation Work of Globalization’ (2002) 27 Law and Social Inquiry 801.
} 
Accepted for Publication, Journal of Law and Society 2019, 46, 4 Winter issue. (pre-publication unproofed version)

precisely because the morality of the struggle itself was so manifest. ${ }^{147}$ However, even amongst the most unswerving of struggle lawyers, their commitment did not equate to a rejection of law as simply a 'tool of domination'. ${ }^{148}$ Not only did they seek to find spaces for material and symbolic resistance but part of their legitimation work also required postulating an alternative imagined version of legality - what Sachs has described as 'realigning law with justice'. ${ }^{149}$ Struggle lawyers who saw themselves as 'lawyering for justice' 150 needed an alternative vision of a legitimate and just political system wherein a real rule of law was perhaps the fundamental prerequisite. It also, of course, served to legitimate some of the actions (including illegal ones) which were required to realise that vision.

In a similar vein, for human rights lawyers, the international human rights framework is itself and was perhaps the key legal resource in verifying the parameters of such legitimation work. In a context where simple 'rule application theory'151 (to compromised local laws or codes of legal ethics) were clearly inadequate as a guide to ethical conduct for cause-lawyers, the international human rights framework was an obvious resource for 'legitimate' professional and ethical guidance. However, as noted above, human rights discourses cannot magically resolve real world dilemmas for cause-lawyers, particularly where moral choices may involve breaking the law. ${ }^{152}$ The primary legitimating utility of the rights framework was thus a politically plausible, self-disciplining but ultimately legalistic means of positioning such lawyers vis a vis their clients and the movements from which they hail. Such a view of both law and lawyers serves as a variant of what Goffman has termed an 'accredited' and viable presentation of the professional self. ${ }^{153}$

For cause lawyers whose actions were largely shaped by the moral community to which they belonged, their legitimacy work tended to be somewhere between that of struggle and human rights lawyers. Their professional choices were pragmatic, less ideological or rule based and more 'dialogic and relational in nature'154 a constant process of engagement, debate and revision on legal strategies and lines to take with military/political movement. ${ }^{155}$ The legitimacy work of such cause-lawyers was

\footnotetext{
${ }^{147}$ In considering law-breaking Luban argues that lawyers may wish to consider 'the morality of their clients' projects', in effect law-breaking to 'press for better laws' thus seeking what he terms law's 'utopian content. See Luban (1991) "Conscientious Lawyers for Conscientious Lawbreakers," 52 University of Pittsburgh Law Review 793. See also W. Simon The Practice of Justice: A Theory of Lawyers' Ethics (2009) Ch. 4.

${ }^{148}$ R. Quinney 'The Ideology of Law: Notes for a Radical Alternative to Legal Oppression.' (1972) 7 Issues in Criminology 1.

149 A. Sachs The Strange Alchemy of Life and Law (2009) p. 1.

${ }^{150}$ S. Ellman 'Lawyering for Justice in a Flawed Democracy,' (1990) 90 Colombia Law Review 116.

${ }^{151}$ D. Luban, 'Epistemology and Moral Education' (1983) 33 Journal of Legal Education 636.

${ }^{152}$ See UN Principles on the Role of Lawyers (1990, principle 13 and 14) which require lawyers to 'uphold human rights' and act 'in accordance with the law and recognised standards and ethics of the legal profession.'

${ }^{153}$ E. Goffman, The Presentation of Self In Everyday Life (1990) p. 45.

154 A. Bottoms and J. Tankebe 'Beyond Procedural Justice: A Dialogic Approach To Legitimacy In Criminal Justice' (2012) Journal of Criminal Law and Criminology,p.119.

155 J. Coicaud Legitimacy and Politics (2002).
} 
Accepted for Publication, Journal of Law and Society 2019, 46, 4 Winter issue. (pre-publication unproofed version)

shaped of course by legal training but also by a reflexive knowledge of the politics and ideology of their clients and their movements and, in particular, the lived experience of other cause-lawyers. In some ways, such lawyers were similar to the legal practitioners discussed by Ewick and Silbey, fusing the normative and regulatory aspects of law with the 'ordinary social logics and local cultural categories and norms' of everyday life. ${ }^{156}$ In these settings, making professional judgements as a lawyer in a context of state violence and armed struggle was a quotidian self-legitimacy challenge.

I want to conclude by making a final point about the ways in which cause-lawyering is remembered. For societies transitioning from conflict or authoritarianism, legitimation work is not something which is completed once the period of 'struggle' is over. Indeed memory wars concerning the legitimacy or not of past actions and contests about the writing and rewriting of history is a defining theme of transitional justice. ${ }^{157}$ As I have argued elsewhere, addressing the role of judges and the legal profession needs to be part of broader transitional justice efforts to understand the context, causes and consequences of past harms as well as ensuring that they do not reoccur. ${ }^{158}$ In most contexts, that reckoning is focused for good reason on how judges and lawyers failed to uphold the rule of law, were silent concerning human rights abuses, did not stand up for other lawyers who were the subject of intimidation or oppression and were otherwise complicit in the wrongs of 'wicked' political and legal systems. ${ }^{159}$ However, I would suggest that there are also significant lessons to be learned from an equivalent respectful but critical exploration of the role of causelawyers who opposed such regimes.

In settled democracies, as Sandra Day O'Connor has remarked, 'lawyers are compared frequently, and unfavourably, with skunks, snakes and sharks'. ${ }^{160}$ Depending of course on one's view of the particular cause to which they are affiliated, cause-lawyers may be seen rather differently. Certainly, for people opposed to the Pinochet regime in Chile, the Ben Ali dictatorship in Tunisia, Apartheid in South Africa, the actions of the Israeli government in the Occupied Territories, or the authoritarian Hun Sen government in Cambodia, the image of lawyers fighting against a repressive state is a powerful one. Cause-lawyering is attractive 'precisely because it is a deeply moral or political activity, a kind of work that encourages pursuit of the right, the good or the just' $^{\prime}{ }^{161}$

\footnotetext{
${ }^{156}$ P. Ewick and S. Silbey. The Common Place of Law: Stories from Everyday Life (1998) p. 18.

${ }^{157}$ E.g. S. Bird et al (eds). The Performance of Memory as Transitional Justice (2015); K. Neumann J. Thompson, eds. Historical Justice and Memory (2015).

${ }^{158}$ K. McEvoy and A. Schwartz 'Judges, Conflict and the Past' Journal of Law and Society (2015) 44, 4528.

${ }^{159}$ See e.g. D. Dyzenhaus, Judging the Judges: Judging Ourselves: Truth, Reconciliation and the Apartheid Legal Order (1998); R Barros 'Dictatorship and the Rule of Law: Rules and Military Power in Pinochet's Chile.' (2003) 5 Democracy and the Rule of Law, p. 188.

${ }^{160}$ S. Day O'Connor, 'Professionalism.' (1998) 76 Wash. U. L. Q. 5. p. 6

${ }^{161}$ Sarat \& Scheingold (1998) op cit p. 3.
} 
Accepted for Publication, Journal of Law and Society 2019, 46, 4 Winter issue. (pre-publication unproofed version)

For example, in South Africa cause-lawyers are widely venerated as 'struggle heroes' in the fight against Apartheid in political discourse, official commemorations and within the legal community. ${ }^{162}$ While acknowledging the enormous contributions made by cause-lawyers, a number of interviewees expressed disquiet at such uncritical acclaim. One prominent South African struggle lawyer described what she saw as a 'veneration for a particular set of lawyers' - male, white lawyers or lawyers of Indian descent - while downplaying the contribution of female and black African lawyers. ${ }^{163}$ Another interviewee, a senior figure in the Defence and Aid Fund which financed much of the anti-Apartheid defence work in South Africa until the early 1990s, told us that while he had 'funded all of the legendary struggle lawyers in South Africa' but that even some amongst these legends were sometimes guilty of overcharging, double jobbing and related sharp practices common to lawyers everywhere. As he told us, 'they [struggle lawyers] were ... well people, you know'. ${ }^{164}$ As several struggle lawyers and one former Truth Commissioner told us, the fact that the South African Truth and Reconciliation Commission judiciary and legal profession hearings examined only Apartheid complicity and not struggle lawyering was a missed opportunity for lawyers and society more generally.

In developing these ideal types and charting different variants of legitimacy work done by cause-lawyers, I have been very aware that cause-lawyers are indeed people - human beings, not saints. In the sites under review, cause-lawyering required moral and political courage and commitment and it entailed significant personal risk and sacrifice. However, there are risks associated with uncritical 'over remembering' of the heroic efforts of cause-lawyers. ${ }^{165}$ In some contexts, focusing only on the powerful imagery of the cause-lawyer as a noble symbol of struggle may serve to underplay the ugly realities of political violence and its consequences. Moreover, uncritical heroic narratives do not do justice to the challenges of being a cause-lawyer in a conflicted or authoritarian society wherein the meaning of professionalism was and is a daily struggle.

\footnotetext{
${ }^{162}$ S. Marschall 'Commemorating 'Struggle Heroes': Constructing a Genealogy for the New South Africa, 2006) 12 International Journal of Heritage Studies, $p$. 176. We saw similar tendencies towards cause-lawyers in Tunisia, and amongst left-leaning political actors and activists in Chile and Israel.

${ }^{163}$ Interview former cause lawyer South Africa, $16^{\text {th }}$ August 2014. The complex intersection between gender and cause-lawyering in these contexts is discussed in A. Bryson and K. McEvoy (2016).

${ }^{164}$ Interview South Africa, $11^{\text {th }}$ August 2014.

${ }^{165}$ P. Ricouer Memory, History, Forgetting (2004).
} 